\title{
UPAYA MENINGKATKAN HASIL BELAJAR MATEMATIKA PADA TRANSFORMASI BANGUN DATAR MELALUI METODA KOOPERATIF MODEL NUMBERED HEADS TOGETHER (NHT) PADA KELAS IIAP 1 SMK NEGERI 1 PAYAKUMBUH TAHUN PELAJARAN 2010/2011
}

\section{Eri Yenis}

\begin{abstract}
Abstrak
Penelitian ini dilatarbelakangi dari hasil Ulangan Harian yang rendah, siswa tidak mau mengerjakan latihan dengan sempurna. Penelitian ini merupakan penelitian tindakan kelas dengan dua siklus. Subjek penelitian yaitu kelas II AP 1 SMK Negeri Payakumbuh. Tujuan Penelitian ini untuk melihat hasil belajar matematika siswa melalui metode kooperatif learning. Hasil penelitian diketahui bahwa (1) hasil belajar siswa kelas II AP 1 Semester 1 SMK Negeri 1 Payakumbuh dengan pokok bahasan Transformasi Bangun Datar dapat ditingkatkan dengan model pembelajaran Numbered Heads Together (NHT), ditunjukkan dengan rata-rata nilai tes akhir siklus I dari 6,33 menjadi 7,16 dan pada siklus II ketuntasan belajar klasikal meningkat pada siklus I sebesar $63,89 \%$ menjadi $86,11 \%$ pada siklus II. (2) dengan strategi pembelajaran Kooperatif model "Numbered Heads Together dapat meningkatkan aktivitas siswa dalam mengikuti pelajaran pada kelas IIAP1. Kesimpulan dari penelitian ini bahwa metode kooperatif learning model Numbered Heads Together dapat digunakan pada siswa SMK.
\end{abstract}

Keyword: Hasil Belajar, metode kooperatif model THT, Transformasi Bangun Datar

Copyright (C) 2016 IICET (Padang - Indonesia) - All Rights Reserved

Indonesian Institute for Counseling, Education and Theraphy (IICET)

\section{PENDAHULUAN}

Pendidikan merupakan faktor utama dalam pembentukan pribadi manusia. Pendidikan sangat berperan dalam membentuk baik atau buruknya pribadi manusia menurut ukuran normatif. Upaya yang dilakukan pemerintah antara lain pengembangan dan penyempurnaan kurikulum, meningkatkan kualitas guru melalui penataran-penataran, melengkapi sarana dan prasarana dan sebagainya.

Pelaksanaan pembelajaran di dalam kelas merupakan salah satu tugas utama guru. Proses pembelajaran dapat diartikan sebagai kegiatan yang ditujukan untuk pembelajaran siswa. Dalam proses pembelajaran, sering ditemui siswa-siswa yang rendah kreativitasnya, sehingga siswa bersifat pasif, mereka lebih banyak menunggu sajian guru dari pada mencari dan menemukan sendiri pengetahuan dan keterampilan yang mereka butuhkan. Siswa yang kurang kreatif ini selalu mengalami kesulitan dan masalah dalam belajar, bakat dan kemampuannya tidak dapat berkembang sebagaimana yang diharapkan. Pada pelajaran matematika yang menghendaki siswa lebih kreatif, banyak siswa yang mengalami kesulitan dalam belajar terutama dalam mengerjakan atau menyelesaikan soal-soal latihan.

Berdasarkan pengalaman penulis selama mengajar matematika di SMK Negeri I Payakumbuh lebih kurang 26 tahun, banyak siswa yang tidak mampu mengerjakan soal-soal latihan matematika dengan sempurna. Dalam proses pembelajaran terlihat kurang aktif, siswa hanya bersifat menerima apa yang diberikan guru saat diberikan soal-soal, siswa yang bertanya tentang konsep dan langkah-langkah penyelesaian soal-soal hanya beberapa orang saja. Siswa yang kurang aktif ini dalam penyelesaian soal-soal selalu tidak sempurna dan tertinggal dari teman-temannya yang lain, keadaan ini mengakibatkan hasil belajar yang mereka capai rendah.

Rendahnya hasil belajar matematika siswa SMK Negeri I Payakumbuh tersebut dapat dilihat pada nilai rata-rata matematika pada ulangan harian semester I seperti ditunjukkan oleh tabel di bawah ini. 


\section{Tabel 1}

Nilai Rata-Rata Ulangan Harian Matematika Siswa Kelas IIAPI SMK Negeri 1 Payakumbuh Tahun Pelajaran 2010/2011.

\begin{tabular}{|c|c|c|c|}
\hline No & Ulangan Harian & Nilai Rata-rata & Ket \\
\hline 1 & $\mathrm{I}$ & 5,70 & \\
\hline 2 & II & 5,50 & \\
\hline 3 & III & 6,00 & \\
\hline
\end{tabular}

Sesuai dengan Kriteria Ketuntasan Minimal (KKM) yang diharapkan untuk siswa jurusan Administrasi Perkantoran (AP) nilai KKM nya adalah 6,50, maka penampakan tabel diatas nilai siswa jauh dibawah nilai KKM yang diharapkan.

Guru sebagai penanggung jawab keberhasilan pengajaran perlu memotivasi siswa, karena dengan meningkatnya motivasi siswa hasil belajar dapat lebih meningkat dan dengan meningkatnya hasil belajar siswa, dapat mendorong siswa lebih bersemangat untuk belajar matematika. Pembelajaran hendaknya dapat meningkatkan aktivitas siswa dalam belajar, seperti dijelaskan oleh Sagala ( 2003 : 63), Pembelajaran mempunyai dua karakteristik yaitu : Pertama, dalam proses pembelajaran melibatkan proses mental siswa secara maksimal, bukan hanya menuntut siswa sekedar mendengar, mencatat akan tetapi menghendaki aktivitas siswa dalam proses berfikir. Kedua, dalam pembelajaran membangun suasana dialogis dan proses tanya jawab terus menerus yang diarahkan untuk memperbaiki dan meningkatkan kemampuan berfikir itu dapat membantu siswa untuk memperoleh pengetahuan yang mereka konstruksi sendiri.

Dalam melaksanakan proses belajar mengajar diperlukan langkah-langkah sistematis untuk mencapai tujuan yang telah ditentukan. Hal yang harus dilakukan dengan menggunakan metode yang cocok dengan kondisi siswa agar siswa dapat berpikir kritis, logis dan dapat memecahkan masalah dengan sikap terbuka, kreatif dan inovatif. Dalam pembelajaran dikenal berbagai model pembelajaran, salah satunya adalah pembelajaran Kooperatif (Cooperative Learning). Sebagian guru berpikir bahwa mereka sudah menerapkan Cooperative Learning tiap kali menyuruh siswa bekerja di dalam kelompok-kelompok kecil. Tetapi guru belum memperhatikan adanya aktivitas kelas yang terstruktur sehingga peran setiap anggota kelompok belum terlihat.

Untuk meningkatkan aktivitas belajar penulis mencari solusinya dengan strategi pembelajaran Kooperatif yaitu belajar dalam kelompok seperti dikemukakan oleh Ismail ( 2007 : 315 ) Belajar Kooperatif memberikan kesempatan yang setara kepada setiap siswa untuk mempertunjukkan kinerja belajar mereka yang tertarik dalam kelompoknya demi keberhasilan kelompok belajar. Karena dengan belajar kelompok siswa akan dapat bertukar pikiran dengan temannya sebagaimana yang dikemukakan oleh Herman Hudoyo (1979:149) pembentukan kelompok belajar dalam mengerjakan soal-soal latihan dalam proses pembelajaran dapat menciptakan situasi belajar siswa yang aktif dan meningkatkan hasil belajar siswa.

Berdasarkan hal diatas penulis tertarik untuk melakukan Penelitian Tindakan Kelas (PTK) dalam upaya meningkatkan aktivitas dan hasil belajar siswa dengan strategi belajar Kooperatif Model kepala bernomor atau strategi Model Numbered Heads Together (NHT) dengan judul : "Upaya Meningkatkan Hasil Belajar Matematika pada Transformasi Bangun Datar melalui Metoda Kooperatif Model Numbered Heads Together (NHT) pada kelas II AP1 SMK Negeri I Payakumbuh Tahun Pelajaran 2010/2011.

\section{METODELOGI PENELITIAN}

Penelitian ini menggunakan pendekatan Tindakan Kelas (PTK). PTK merupakan bentuk penelitian yang bertujuan untuk memecahkan persoalan-persoalan di kelas melalui metode ilmiah. Dalam hal ini tindakan yang diberikan adalah memotivasi siswa mengerjakan latihan melalui kerja kelompok. Selama penelitian berlangsung peneliti melihat perubahan-perubahan aktivitas dan hasil belajar siswa pada setiap sub pokok bahasan. Menurut Lutfian Almash dkk (1998 : 4 ), PTK bersifat "self-evaluatif", yaitu modifikasi-modifikasi dilakukan secara kontinu dan berlangsung secara terus menerus oleh guru (peneliti) yang tujuannya adalah untuk peningkatan dan perbaikan.

Sebagai subjek penelitian adalah siswa-siswa kelas II program keahlian Administrasi Perkantoran ( II AP 1 ) SMK Negeri 1 Payakumbuh Tahun Pelajaran 2010 / 2011 yang berjumlah 36 orang terdiri dari 30 orang perempuan dan 6 orang laki-laki. Pelaksanaan tindakan berdasarkan Kompetensi Dasar "Menerapkan 
Transformasi Bangun Datar”. Penelitian ini dilaksanakan dua siklus. Siklus pertama dilakukan dua kali pertemuan ( 4 x40 menit) dan siklus kedua, 2 kali pertemuan (4x40 menit).

\section{Perencanaan}

Sebelum melaksanakan penelitian penulis melakukan persiapan awal yaitu :

a) Menyusun rincian jadwal kegiatan tatap muka di kelas.

b) Menetapkan materi yang diajarkan selama penelitian berlangsung.

c) Menyiapkan Rencana Pelaksanaan Pembelajaran (RPP) dengan materi sebagai berikut :

- Menentukan koordinat bayangan dari Translasi.

- Menentukan koordinat bayangan dari jenis-jenis Refleksi.

- Menentukan koordinat bayangan dari jenis-jenis Rotasi.

- Menentukan koordinat bayangan dari jenis-jenis Dilatasi.

- Menentukan matriks yang bersesuaian dengan jenis-jenis Transformasi.

- Menentukan koordinat bayangan dari komposisi Transformasi.

d) Membagi siswa atas beberapa kelompok sesuai dengan strategi pembelajaran Kooperatif model NHT.

e) Membuat lembar kerja siswa (LKS) sebagai media pembelajaran.

f) Menyiapkan latihan untuk PR.

g) Mempersiapkan lembar observasi aktivitas siswa dalam kelompok.

\section{Pelaksanaan tindakan}

Pelaksanaan tindakan pembelajaran siklus 1 terdiri dari dua kali pertemuan yaitu pada Transformasi Bangun Datar.. Tindakan yang dilakukan adalah proses pembelajaran sesuai dengan pembelajaran Kooperatif model Numbered Heads Together (NHT) sebagai berikut :

\section{Pertemuan 1}

a) Pendahuluan

- Guru mengucapkan salam untuk membuka pembelajaran

- Guru menyampaikan tujuan pembelajaran.

b) Kegiatan Inti

- Guru membagi siswa menjadi kelompok-kelompok belajar heterogen yang terdiri dari 4 - 5 siswa pada setiap anggota kelompok diberi nomor $1-5$, kemudian setiap siswa diberi LKS.

- $\quad$ Siswa membaca dan mempelajari materi yang sesuai dengan RPP.

- Guru memberikan pertanyaan yang berkaitan dengan materi yang dituangkan dalam LKS.

- $\quad$ Dengan diskusi kelompok siswa menyatukan pendapatnya untuk memberikan jawaban dan memastikan setiap anggota memahami jawaban yang diajukan ( selama diskusi berlangsung, guru memantau kerja setiap kelompok dan mengarahkan siswa yang mengalami kesulitan ).

- Siswa bersama guru membahas soal yang ada di LKS.

- Guru memanggil satu nomor secara acak, setelah itu siswa yang nomornya sesuai dengan nomor yang dipanggil diminta untuk mengangkat tangannya dan menjawab pertanyaan no.1 secara bergantian, kemudian anggota kelompok lain memberikan tanggapannya, seterusnya dengan cara yang sama untuk nomor soal 2, 3, 4, dan 5 .

- Guru memberikan penghargaan terhadap kelompok berdasarkan jawaban setiap anggota kelompok terhadap pertanyaan yang diajukan pada LKS.

c) Penutup

- $\quad$ Guru menegaskan kembali poin-poin penting mengenai materi yang sudah dipelajari.

- $\quad$ Menugaskan siswa untuk mengerjakan soal-soal latihan pekerjaan rumah ( PR ).

Pada pertemuan kedua dan seterusnya tindakan yang dilakukan sama dengan pertemuan pertama, tetapi pada tahap pendahuluan kegiatan guru, terlebih dahulu dimulai dengan mengumpulkan latihan dan membahas soal-soal yang tidak dapat diselesaikan siswa.

\section{Pengamatan}

Hal-hal yang diamati adalah aktivitas verbal dan aktifitas non verbal. Pengamatan dilakukan oleh teman sejawat dan peneliti sendiri dengan data yang diamati adalah kuantitatif dan data kualitatif. Keduanya akan dianalisis dan hasilnya akan dijadikan sebagai bahan kajian pada kegiatan refleksi, antara lain interaksi siswa dengan siswa, interaksi siswa dengan guru, aktivitas dalam kerja kelompok dan lain-lain. 


\section{Refleksi}

Refleksi adalah upaya mengkaji apa yang telah terjadi, yang telah dihasilkan pada langkah sebelumnya melalui refleksi diperoleh tindakan apa yang akan dilakukan berikutnya. Dari aktivitas yang dilakukan siswa selama mengikuti pelajaran diteliti sampai dimana peningkatan aktivitas siswa. Hasil belajar akan meningkat apabila aktivitas belajar meningkat.

Refleksi pada siklus I dilaksanakan segera setelah tahap pelaksanaan tindakan selesai. Refleksi siklus I meliputi hasil observasi dan hasil tes evaluasi siklus I, hasil refleksi pada siklus I ini digunakan sebagai acuan pelaksanaan siklus 2 .

Instrumen penelitian yang dipakai dalam penelitian ini adalah Lembaran pengamatan yang berisikan aktivitas siswa dalam belajar. Teknik analisis data pada tindakan ini terdiri dari dua macam yaitu untuk melihat hasil belajar digunakan rata-rata hitung dengan rumus menurut Sujana ( 1988 ). Melihat aktivitas siswa digunakan Teknik analisis data dengan rumus yang dikemukakan oleh Elly Warnelis ( 2001:15). Muhammad Uzer Usman ( 1996:119) membagi standar penilaian secara kuantitatif dengan sebutan : 1) Kurang sekali, 2) Kurang, 3) Sedang, 4)Baik dan 5) baik sekali.

\section{HASIL DAN PEMBAHASAN PENELITIAN \\ HASIL PENELITIAN \\ Siklus I}

Pada siklus I, dari setiap pertemuan menunjukkan peningkatan aktivitas belajar siswa. Seperti meningkatnya antusias dan motivasi siswa dalam mengikuti pembelajaran, karena dorongan dan pemberian motivasi oleh guru. Untuk kerja kelompokpun menunjukkan aktivitas, seperti meningkatnya diskusi dan tanya jawab antar teman dalam kelompok, serta dalam mengkaji ulang / melakukan evaluasi dan membuat kesimpulan juga semakin meningkat namun ini belum menunjukkan aktivitas yang dilaksanakan siswa optimal sesuai dengan yang diharapkan karena masih ada siswa yang tidak mau berinteraksi dengan sesamanya sehingga perlu ditingkatkan, seperti terlihat pada tabel pengamatan dibawah ini :

Tabel 4

Lembaran Pengamatan Aktivitas Siswa

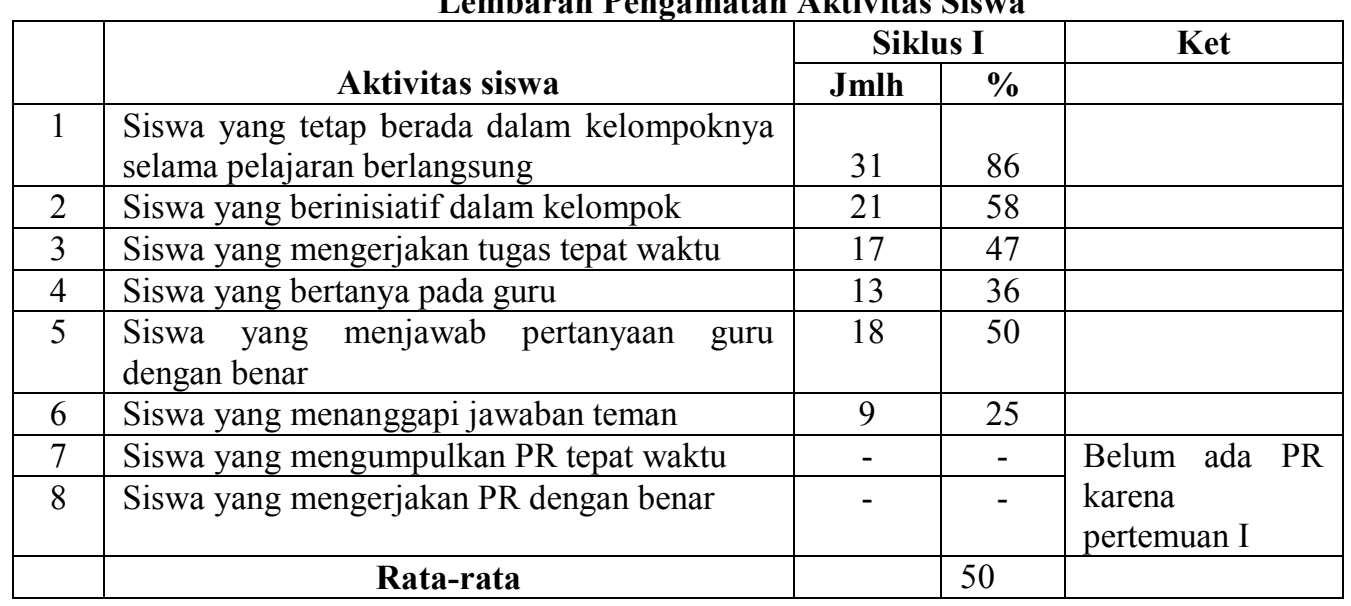

Sesuai dengan interval yang diberikan oleh Suharsimi Arikunto (1989) maka dapa dikemukakan :

1. Siswa yang berada dalam kelompoknya selama pembelajaran berlangsung adalah $86 \%$ (baik sekali)

2. Siswa yang berinisiatif dalam kelompok $58 \%$ ( sedang)

3. Siswa yang mengerjakan tugas tepat waktu $47 \%$ (sedang)

4. Siswa yang bertanya pada guru $36 \%$ (kurang)

5. Siswa yang menjawab pertanyaan guru dengan benar $50 \%$ (sedang)

6. Siswa yang menanggapi jawaban teman $25 \%$ (kurang)

Dari data diatas ada peningkatan aktivitas, jika dirata-ratakan, maka rata-rata aktivitas siswa hanya $50 \%$ tergolong sedang. Hasil ulangan harian pada siklus I didapatkan rata-ratanya adalah 6,33 berarti ada peningkatan dibandingkan dengan rata-rata nilai ulangan harian sebelumnya. Tabel dibawah ini adalah hasil yang diperoleh siswa pada ulangan harian siklus I. 
Tabel 5

Data Nilai Ulangan Harian Siklus I

\begin{tabular}{|c|c|c|c|c|c|c|c|c|c|c|}
\hline & \multirow{3}{*}{$\begin{array}{l}\text { Nama } \\
\text { Siswa }\end{array}$} & & & & & & & & \multirow{2}{*}{\multicolumn{2}{|c|}{$\begin{array}{c}\text { Ketuntasan } \\
\text { Belajar }\end{array}$}} \\
\hline \multirow[t]{2}{*}{ No } & & \multicolumn{5}{|c|}{ Skor Perolehan } & \multirow[t]{2}{*}{ Nilai } & \multirow{2}{*}{$\begin{array}{c}\text { Ketun } \\
\text { tasan } \\
\text { Perora } \\
\text { ngan } \\
(\%)\end{array}$} & & \\
\hline & & 2,5 & 2,5 & 1,5 & 1,5 & 2,0 & & & Ya & Tidak \\
\hline 1 & $\mathrm{AG}$ & 2,0 & 2,0 & 1,25 & 1,25 & 1,5 & 8,0 & 80 & $\mathrm{v}$ & \\
\hline 2 & AT & 2,5 & 1,5 & 1,0 & 1,0 & 2,0 & 8,0 & 80 & $\mathrm{~V}$ & \\
\hline 3 & $\mathrm{DF}$ & 1,5 & 1,0 & 1,0 & 1,0 & 1,5 & 6,0 & 60 & & $\mathrm{v}$ \\
\hline 4 & DR & 1,0 & 2,0 & 1,5 & 1,0 & 1,5 & 7,0 & 70 & $\mathrm{v}$ & \\
\hline 5 & DR & 1,0 & 1,5 & 1,5 & 1,0 & 1,0 & 6,0 & 60 & & $\mathrm{v}$ \\
\hline 6 & DP & 2,0 & 2,0 & 1,25 & 1,25 & 1,5 & 8,0 & 80 & $\mathrm{v}$ & \\
\hline 7 & FY & 1,0 & 1,5 & 1,5 & 1,0 & 1,0 & 6,0 & 60 & & $\mathrm{v}$ \\
\hline 8 & $\mathrm{FN}$ & 1,5 & 1,0 & 1,0 & 1,5 & 1,5 & 6,5 & 65 & $\mathrm{v}$ & \\
\hline 9 & IS & 2,5 & 2,5 & 1,5 & 1,5 & 2,0 & 10 & 100 & $\mathrm{~V}$ & \\
\hline 10 & LE & 0,0 & 1,0 & 1,0 & 1,5 & 0,5 & 4,0 & 40 & & $\mathrm{~V}$ \\
\hline 11 & LM & 2,5 & 2,0 & 1,25 & 1,25 & 2,0 & 9,0 & 90 & $\mathrm{~V}$ & \\
\hline 12 & MM & 1,0 & 1,5 & 1,0 & 1,5 & 1,5 & 6,5 & 65 & $\mathrm{~V}$ & \\
\hline 13 & MY & 1,5 & 1,0 & 1,0 & 1,0 & 2,0 & 6,5 & 65 & $\mathrm{~V}$ & \\
\hline 14 & MK & 2,0 & 1,5 & 1,5 & 0,5 & 1,0 & 6,5 & 65 & $\mathrm{~V}$ & \\
\hline 15 & $\mathrm{NF}$ & 1,5 & 1,0 & 1,0 & 1,0 & 2,0 & 6,5 & 65 & $\mathrm{~V}$ & \\
\hline 16 & $\mathrm{NH}$ & 1,0 & 0,5 & 1,0 & 0,0 & 1,0 & 3,5 & 35 & & $\mathrm{~V}$ \\
\hline 17 & NA & 2,0 & 2,0 & 1,0 & 1,0 & 1,0 & 7,0 & 70 & $\mathrm{~V}$ & \\
\hline 18 & NJ & 2,0 & 1,5 & 1,5 & 0,5 & 1,0 & 6,5 & 65 & $\mathrm{~V}$ & \\
\hline 19 & $\mathrm{NN}$ & 1,5 & 1,0 & 1,5 & 1,0 & 0,0 & 5,0 & 50 & & $\mathrm{~V}$ \\
\hline 20 & ND & 1,0 & 2,0 & 1,5 & 1,0 & 1,5 & 7,0 & 70 & $\mathrm{~V}$ & \\
\hline 21 & NS & 0,0 & 1,0 & 1,0 & 1,5 & 0,0 & 3,5 & 35 & & $\mathrm{~V}$ \\
\hline 22 & PS & 2,0 & 1,0 & 1,5 & 0,5 & 1,0 & 6,0 & 60 & & $\mathrm{~V}$ \\
\hline 23 & PY & 1,0 & 2,0 & 1,5 & 1,0 & 1,5 & 7,0 & 70 & $\mathrm{~V}$ & \\
\hline 24 & RY & 1,0 & 1,5 & 1,5 & 1,5 & 1,0 & 6,5 & 65 & $\mathrm{~V}$ & \\
\hline 25 & RH & 2,0 & 1,5 & 1,5 & 0,5 & 1,0 & 6,5 & 65 & $\mathrm{~V}$ & \\
\hline 26 & RA & 2,0 & 1,0 & 1,5 & 0,5 & 1,0 & 6,0 & 60 & & $\mathrm{~V}$ \\
\hline 27 & RA & 2,0 & 1,0 & 1,0 & 1,0 & 2,0 & 7,0 & 70 & $\mathrm{~V}$ & \\
\hline 28 & $\mathrm{SS}$ & 1,0 & 1,5 & 1,0 & 0,0 & 1,0 & 4,5 & 45 & & $\mathrm{~V}$ \\
\hline 29 & SG & 0,0 & 1,5 & 0,5 & 0,0 & 0,0 & 2,0 & 20 & & $\mathrm{~V}$ \\
\hline 30 & $\mathrm{SL}$ & 1,0 & 2,0 & 1,5 & 1,0 & 1,5 & 7,0 & 70 & $\mathrm{~V}$ & \\
\hline 31 & VA & 1,5 & 1,0 & 1,0 & 1,5 & 0,0 & 5,0 & 50 & & $\mathrm{~V}$ \\
\hline 32 & $\mathrm{VK}$ & 1,0 & 2,0 & 1,5 & 1,0 & 1,5 & 7,0 & 70 & $\mathrm{~V}$ & \\
\hline 33 & WF & 2,0 & 1,5 & 1,0 & 1,0 & 1,0 & 6,5 & 65 & $\mathrm{~V}$ & \\
\hline 34 & WD & 2,0 & 2,0 & 1,0 & 1,0 & 1,0 & 7,0 & 70 & $\mathrm{~V}$ & \\
\hline 35 & YM & 1,0 & 2,0 & 1,5 & 1,0 & 1,5 & 7,0 & 70 & $\mathrm{~V}$ & \\
\hline \multirow[t]{2}{*}{36} & YA & 1,5 & 1,0 & 1,0 & 1,0 & 1,5 & 6,0 & 60 & & $\mathrm{~V}$ \\
\hline & \multicolumn{6}{|c|}{ Rata-rata } & 6,33 & & & \\
\hline
\end{tabular}

\section{Refleksi dari siklus I}

Dari hasil pengamatan pada siklus I, dimana aktivitas belajar siswa masih tergolong sedang sehingga masih perlu perbaikan, dan untuk hasil belajar sudah ada peningkatan yang berarti namun demikian perlu perbaikan untuk lebih meningkat lagi. Revisi tindakan- tindakan yang akan dilakukan pada siklus berikutnya yaitu :

1) Perlu peningkatan aktivitas siswa untuk berinteraksi dalam kelompoknya. 
2) Kepada siswa untuk lebih dulu membaca materi yang akan diajarkan.

Siklus 2

Pada siklus ke 2 hasil yang didapat untuk aktivitas siswa ada peningkatan yaitu rata-ratanya 69,6 ini tergolong baik menurut nilai aktivitas yang dikemukakan Suharsimi Arikunto (1989). Tabel berikut menunjukkan aktivitas belajar siswa pada siklus 2 yang diambil dari tabel pengamatan pada pertemuan kedua pada siklus 2 .

Tabel 6

Data aktifitas siswa pada siklus 2 pertemuan ke 2.

\begin{tabular}{|c|l|c|c|c|}
\hline & \multicolumn{1}{|c|}{ Aktivitas siswa } & \multicolumn{1}{c|}{ Siklus 2 } & Ket \\
\cline { 3 - 4 } & \multicolumn{1}{|c|}{ Jmlh } & \% & \\
\hline 1 & $\begin{array}{l}\text { Siswa yang tetap berada dalam kelompoknya selama } \\
\text { pelajaran berlangsung }\end{array}$ & 34 & 94 & \\
\hline 2 & Siswa yang berinisiatif dalam kelompok & 25 & 69 & \\
\hline 3 & Siswa yang mengerjakan tugas tepat waktu & 24 & 67 & \\
\hline 4 & Siswa yang bertanya pada guru & 20 & 56 & \\
\hline 5 & Siswa yg menjwb pertnyaan guru dgn benar & 25 & 69 & \\
\hline 6 & Siswa yang menanggapi jawaban teman & 18 & 50 & \\
\hline 7 & Siswa yang mengumpulkan PR tepat waktu & 30 & 83 & \\
\hline 8 & Siswa yang mengerjakan PR dengan benar & 25 & 69 & \\
\hline & Rata-rata & & $\mathbf{6 9 , 6}$ & \\
\hline
\end{tabular}

Tabel 7

Data Persentase Kenaikan Aktivitas Belajar Matematika Siswa

Kelas II AP1 SMK Negeri 1 Payakumbuh.

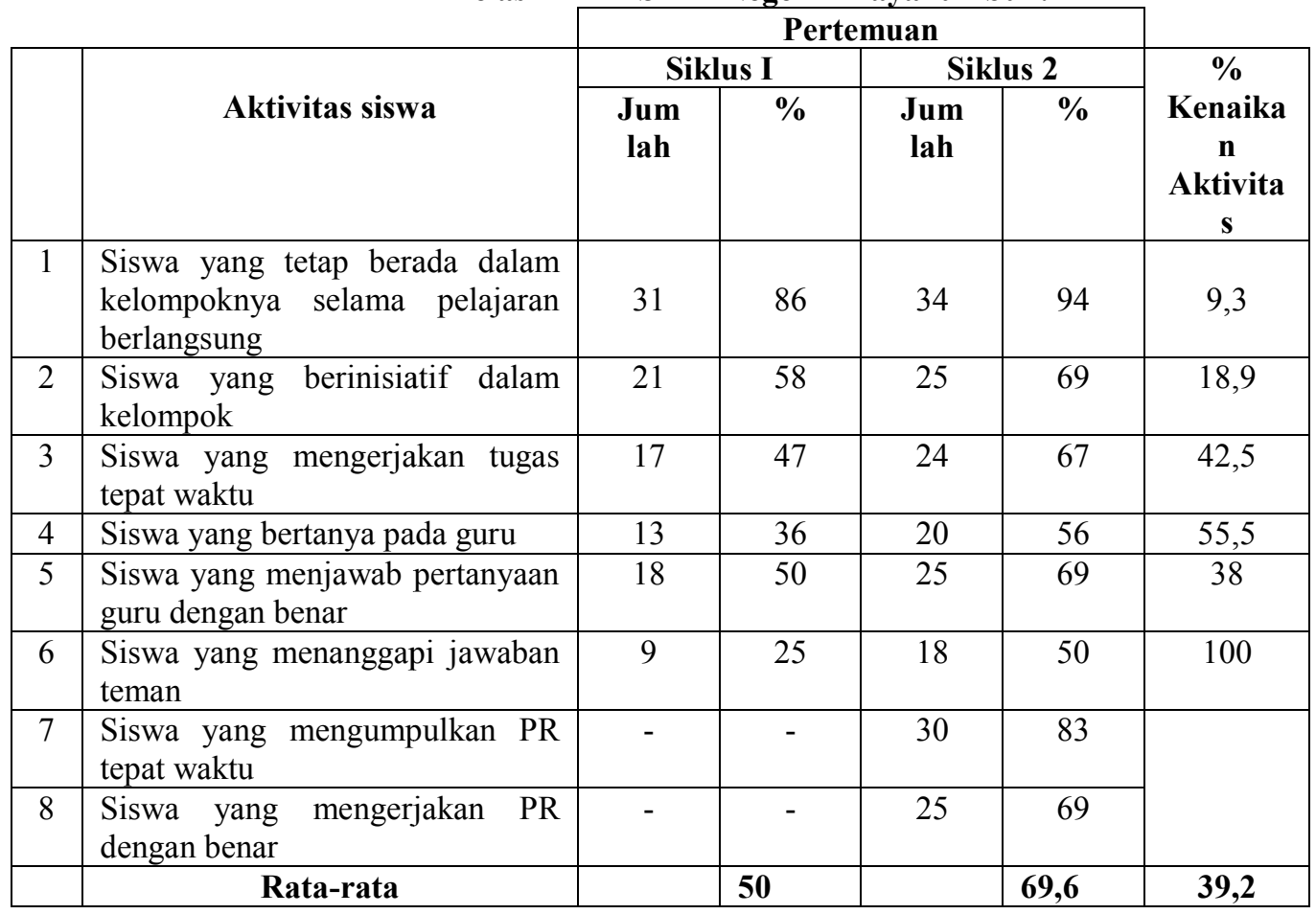

Data diatas menunjukkan perbandingan aktivitas pada siklus I dengan aktivitas pada siklus 2, data untuk siklus 1 diambil pada pertemuan pertama pada Senin 20 September 2010 dan data pada siklus 2 diambil pada pertemuan ke 2 siklus ke 2 Senin 4 Oktober 2010. 
Pada siklus 2 aktivitas siswa lebih meningkat dibandingkan dengan siklus 1, ditandai dengan perolehan rata-rata aktivitas siswa siklus 1 adalah $50 \%$, sedangkan pada siklus 2 rata-rata aktivitas siswa 69,9 $\%$, yang tergolong baik. Hal ini menunjukkan siswa dalam melakukan aktivitas lebih terarah pada kerjasama kelompok, meningkatnya diskusi dan tanya jawab dalam kelompok. Siswa lebih berani mengungkapkan pendapatnya. Walaupun pencapaian dari masing-masing komponen masih ada kategori sedang seperti, siswa yang bertanya pada guru mencapai 56\% ( sedang ) dan yang menanggapi pertanyaan teman $50 \%$ ( sedang ). Perbandingan aktivitas siswa pada siklus 1 dengan aktivitas siswa pada siklus 2 dapat juga dilihat pada grafik batang dibawah ini :

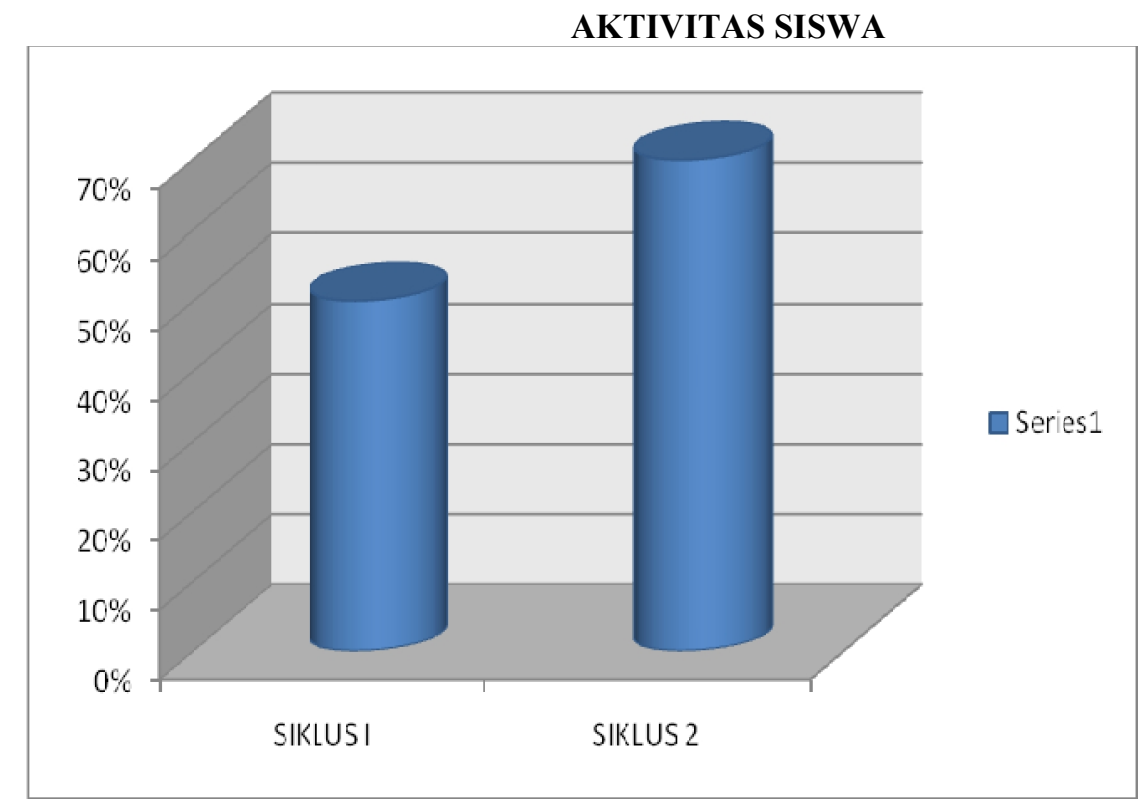

Hasil belajar yang diamati pada ulangan harian siklus 2 didapatkan rata-ratanya 7,16, berarti ada peningkatan dibandingkan rata-rata siklus sebelumnya yaitu 6,33, ini berarti ada peningkatan 13,11\% dari siklus sebelumnya.

Tabel 8

Data Nilai Ulangan Harian Siklus 2

\begin{tabular}{|c|c|c|c|c|c|c|c|c|c|}
\hline \multirow[t]{2}{*}{ No } & \multirow{2}{*}{$\begin{array}{l}\text { Nama } \\
\text { Siswa }\end{array}$} & \multicolumn{4}{|c|}{ Skor Perolehan } & \multirow[t]{2}{*}{ Ni lai } & \multirow{2}{*}{$\begin{array}{c}\text { Ketuntasan } \\
\text { Perorangan } \\
(\%)\end{array}$} & \multicolumn{2}{|c|}{$\begin{array}{c}\text { Ketuntasan } \\
\text { Belajar }\end{array}$} \\
\hline & & 2,5 & 2,5 & 3,0 & 2,0 & & & $\mathrm{Ya}$ & Tidak \\
\hline 1 & $\mathrm{AG}$ & 2,5 & 2,5 & 2,0 & 1,0 & 8,0 & 80 & $\mathrm{v}$ & \\
\hline 2 & AT & 2,5 & 2,5 & 2,0 & 1,5 & 8,5 & 85 & $\mathrm{~V}$ & \\
\hline 3 & DF & 2,0 & 2,0 & 2,0 & 2,0 & 8,0 & 80 & $\mathrm{~V}$ & \\
\hline 4 & DR & 2,0 & 2,0 & 2,0 & 2,0 & 8,0 & 80 & $\mathrm{~V}$ & \\
\hline 5 & DR & 1,5 & 2,5 & 1,0 & 2,0 & 7,0 & 70 & $\mathrm{~V}$ & \\
\hline 6 & DP & 2,5 & 2,0 & 2,0 & 1,5 & 8,0 & 80 & $\mathrm{~V}$ & \\
\hline 7 & $\mathrm{FY}$ & 1,5 & 1,5 & 1,5 & 2,0 & 6,5 & 65 & $\mathrm{~V}$ & \\
\hline 8 & $\mathrm{FN}$ & 2,0 & 2,5 & 1,0 & 1,5 & 7,0 & 70 & $\mathrm{~V}$ & \\
\hline 9 & IS & 2,5 & 2,5 & 3,0 & 2,0 & 10 & 100 & $\mathrm{~V}$ & \\
\hline 10 & LE & 2,0 & 1,5 & 1,0 & 1,5 & 6,0 & 60 & & $\mathrm{~V}$ \\
\hline 11 & LM & 2,5 & 2,0 & 3,0 & 1,5 & 9,0 & 90 & $\mathrm{~V}$ & \\
\hline 12 & MM & 2 & 1,5 & 2 & 2 & 7,5 & 65 & $\mathrm{~V}$ & \\
\hline 13 & MY & 1,5 & 1,5 & 2 & 2,5 & 7,5 & 65 & $\mathrm{~V}$ & \\
\hline 14 & MK & 2,0 & 1,5 & 2,0 & 2,0 & 7,5 & 75 & $\mathrm{~V}$ & \\
\hline 15 & NF & 2,5 & 1,5 & 2,0 & 1,5 & 7,5 & 75 & $\mathrm{~V}$ & \\
\hline
\end{tabular}




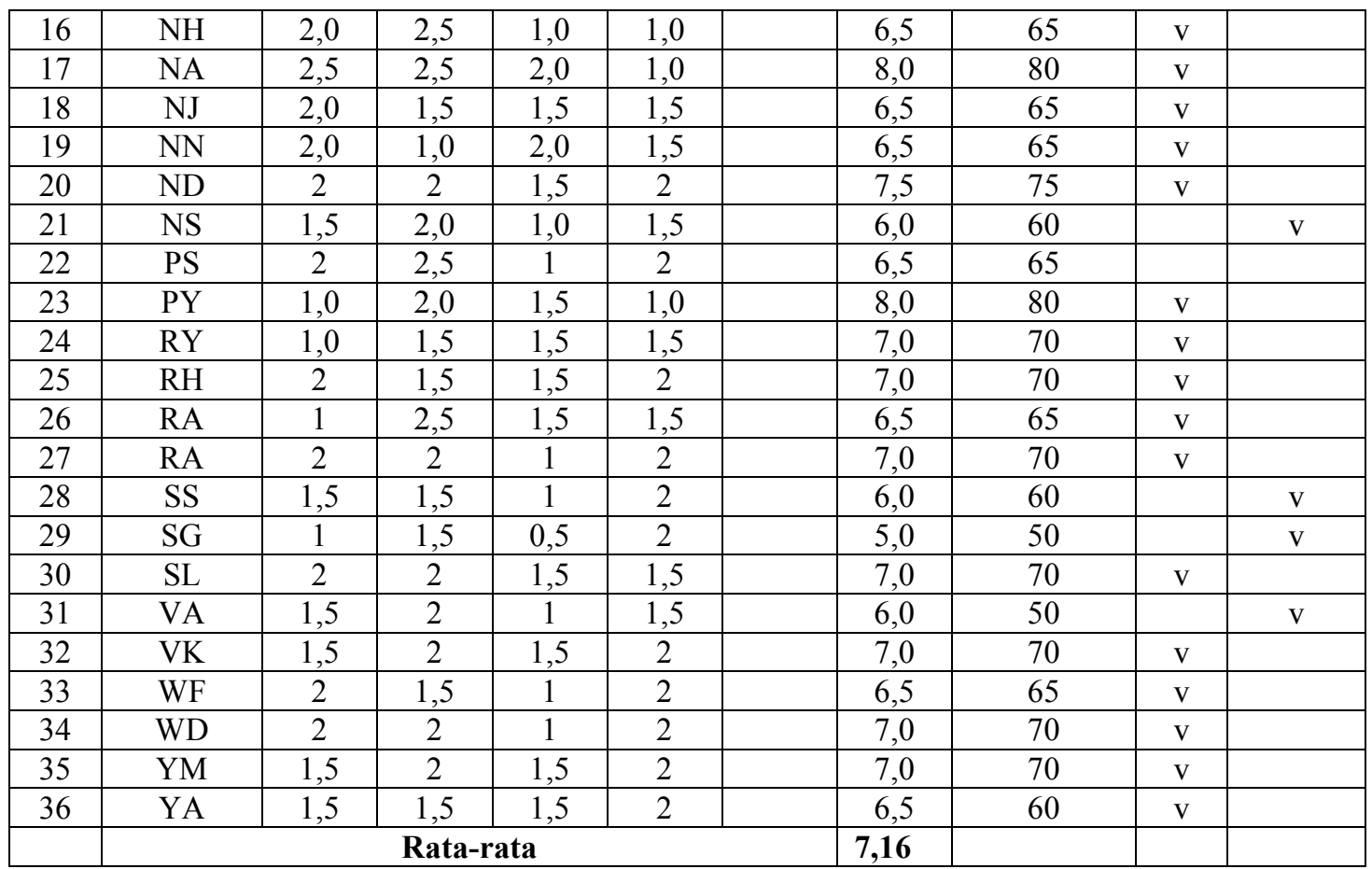

\section{Refleksi siklus 2}

Tabel di atas terlihat ada peningkatan dimana siswa yang tidak tuntas pada siklus 2 hanya 5 orang, sedangkan pada siklus I ada 13 orang. Untuk rata-rata juga terjadi peningkatan, rata-rata ulangan harian pada siklus 2 adalah 7,16 sedangkan rata-rata pada siklus I adalah 6,33 jadi ada kenaikan sebesar 13,11\% dari sebelumnya. Untuk perbandingan nilai yang diperoleh dari kedua siklus dapat dilihat dengan diagram batang sebaga berikut :

Perbandingan Nilai Siklus I dan Siklus 2 :

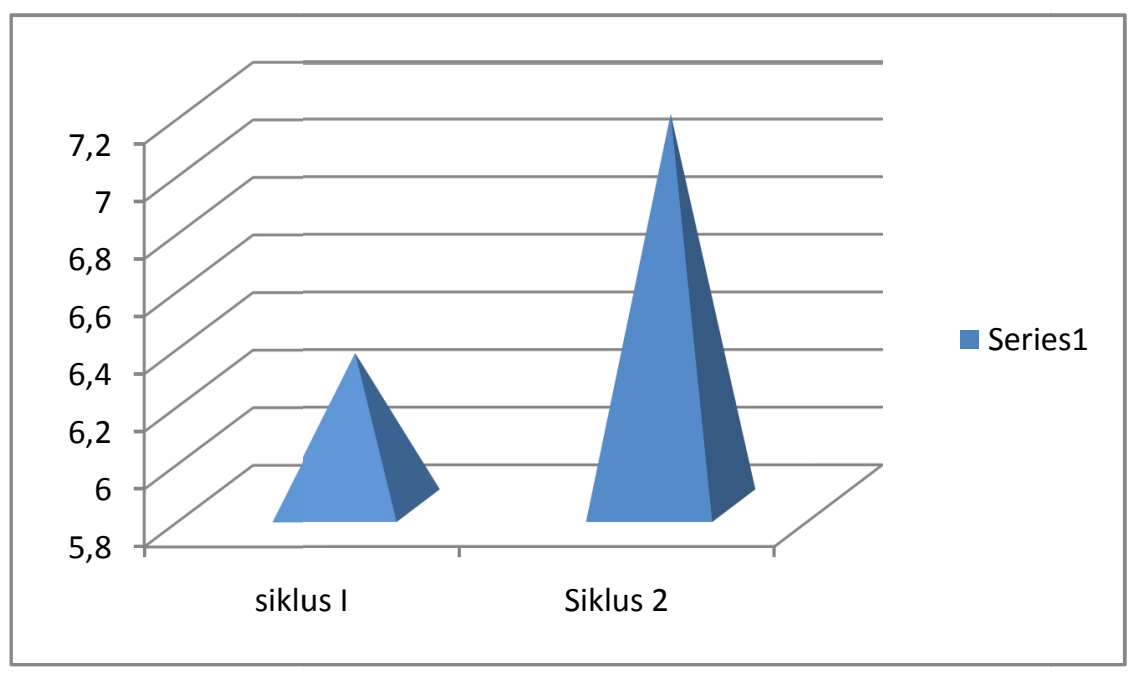

\section{Pembahasan}

Hasil pengamatan kedua siklus, untuk aktivitas belajar dapat dilihat seperti, untuk siswa yang menanggapi pertanyaan teman mendapat kenaikan tertinggi yaitu $100 \%$, kemudian diikuti dengan peningkatan aktivitas siswa yang bertanya kepada guru yaitu 55,5\%. Secara umum ada peningkatan yang 
signifikan. Untuk hasil belajar kenaikannya yaitu dari rata- rata 6,33 pada siklus I dan rata-rata 7,16 pada siklus 2, kenaikannya adalah 13,11\%. Dari uraian analisis data diatas, maka dapat diambil kesimpulan, bahwa belajar dengan Metoda Kooperatif Model Numbered Heads Together (NHT) dapat meningkatkan aktivitas dan hasil belajar siswa kelas II AP 1 SMK Negeri 1 Payakumbuh Tahun Pelajaran 2010 / 2011.

\section{KESIMPULAN DAN SARAN}

\section{KESIMPULAN}

Berdasarkan hasil penelitian dan pembahasan diatas dapat disimpulkan sebagai berikut :

1. Hasil belajar siswa kelas II AP 1 Semester 1 SMK Negeri 1 Payakumbuh dengan pokok bahasan Transformasi Bangun Datar dapat ditingkatkan dengan model pembelajaran Numbered Heads Together (NHT), ditunjukkan dengan rata-rata nilai tes akhir siklus I dari 6,33 menjadi 7,16 dan pada siklus II ketuntasan belajar klasikal meningkat pada siklus I sebesar 63,89 \% menjadi 86,11\% pada siklus II.

2. Dengan strategi pembelajaran Kooperatif model "Numbered Heads Together dapat meningkatkan aktivitas siswa dalam mengikuti pelajaran pada kelas IIAP1.

\section{SARAN}

Dengan memperhatikan hasil penelitian yang telah dilakukan maka kepada rekan-rekan sejawat khususnya guru matematika, penulis sarankan :

1. Guru dalam mengajar perlu memperhatikan paradigma-paradigma baru sehingga dalam mengajar tidak monoton.

2. Kita sebagai pendidik hendaknya mencari model-model pembelajaran alternatif sehingga aktivitas belajar meningkat, salah satunya yaitu dengan strategi pembelajaran kooperatif model "Numbered Heads Together".

3. Guru-guru hendaknya mempunyai inisiatif untuk meningkatkan hasil belajar siswa dan menemukan ideide baru dalam memberikan model-model pembelajaran sesuai dengan materi yang diberikan.

4. Guru dalam mengajar perlu menjadikan siswa sebagai jiwa dengan potensi yang lebih, sehingga guru cukup sebagai fasilitator agar siswa dapat mengembangkan kemampuannya dengan sebaik-baiknya.

5. Model pembelajaran Numbered heads Together dapat digunakan sebagai variasi yang bisa dicobakan guru dalam mengajar sub pokok bahasan yang lain.

\section{DAFTAR PUSTAKA}

Almash, Lutfian, dkk, 1998. Penelitian Tindakan Kelas, Padang : IKIP Padang

A.M Sardiman, 1986. Interaksi dan Motivasi Belajar Mengajar, Jakarta : Rajawali Citra.

Ani, Tri C, 2004. Psikologi Belajar, Semarang : UPT UNNES Press.

Arikunto Suharsimi, 1989. Dasar-Dasar Evaluasi Pendidikan, Bandung : Bumi Aksara.

Dimyati \& Mudjiono, 2002. Belajar dan Pembelajara, Jakarta : Reneka Cipta.

Hamalik, O, 2001. Proses Belajar Mengajar, Jakarta : Bumi Aksara.

Hudoyo Herman, Pengembangan Kurikulum Matematika dan Pelaksanaannya di Depan kelas, Surabaya : Indonesia Usaha Nasional.

Ibrahim, M, dkk, 2000. Pembelajaran Kooperatif, Surabaya : Universitu Press.

Ismail, 2007. Pembaharuan dalam Pembelajaran Matematika, Jakarta : Universitas Indonesia.

Prayitno, Elida, 1973. Motivasi Dalam Belajar, Jakarta : PPLPTK

Sagala, 2003. Konsep dan Materi Pembelajaran, Bandung : Alfa Beta.

Sudjana, Nana, 2001. Penilaian Hasil Belajar Mengajar. Bandung : Remaja Rosdakarya.

Uzer Usman, Muhammad, 1996. Menjadi guru Profesional, Bandung : Rosda Karya Ofset. 